This item was submitted to Loughborough's Research Repository by the author.

Items in Figshare are protected by copyright, with all rights reserved, unless otherwise indicated.

\title{
How do they do it? Understanding back office efficiency savings made by English councils
}

PLEASE CITE THE PUBLISHED VERSION

http://dx.doi.org/10.1108/09513551211223776

PUBLISHER

(c) Emerald Group

VERSION

AM (Accepted Manuscript)

\section{PUBLISHER STATEMENT}

This work is made available according to the conditions of the Creative Commons Attribution-NonCommercialNoDerivatives 4.0 International (CC BY-NC-ND 4.0) licence. Full details of this licence are available at: https://creativecommons.org/licenses/by-nc-nd/4.0/

\section{LICENCE}

CC BY-NC-ND 4.0

\section{REPOSITORY RECORD}

Buxton, Rosamund Chester, and Zoe J. Radnor. 2019. "How Do They Do It? Understanding Back Office Efficiency Savings Made by English Councils”. figshare. https://hdl.handle.net/2134/26347. 


\section{How do they do it?: Understanding Back Office Efficiency Savings made by English Councils}

\section{Structured Abstract}

Purpose: The purpose of this paper is to illustrate the back office efficiency savings made by English councils during the 2004 Spending Review (SR04) period in order to consider the relationship between service delivery, audit and inspection and, efficiency programmes in local government. It considers three research questions; the use of secondary data, the relationship between efficiency savings and contextual factors and, the influence of audit and inspection in delivering efficient public services.

Methodologyl Design: Through statistical analysis the paper discusses the secondary analysis of publicly available sets of administrative data about local councils in England. These datasets are the Annual Efficiency Statements (AES) taken from records made by each council. The paper discusses through the analysis of the AES the degree of efficiency savings and service improvements in English councils and, whether efficiency savings are influenced by internal or external contextual factors.

Findings: The paper illustrates that secondary data is a useful source of data but finds that although Councils have achieved the efficiency savings set there is no relationship with the contextual factors. The paper considers the influence of audit and inspection suggesting that the focus has been on meeting the target rather than local needs.

Originalityl Value: This paper aims to contribute to the debate regarding the use of performance indicators, audit and inspection and efficiency achievement within Local Government. The paper starts to explore the implication in the UK where, after a decade of use, the influence of these are reducing dramatically. 


\section{How do they do it?: Understanding Back Office Efficiency Savings made by English Councils}

\section{Introduction}

UK governments since 1979 have developed a range of mechanisms to bring about change and improvement in the performance of public services. This paper considers on what Downe and Martin (2006) describe as the phases of 'modernisation' since 1997 as central government has tried to transform the politics and performance of English local government. A common feature of the reform movements over the last thirty years, and particularly over the last decade has been a commitment to increased efficiency. The paper considers the relationship between service delivery, audit and inspection and, efficiency programmes in local government showing that efficiency savings have been achieved but not necessarily influenced by audit and inspection or the desire to delivery quality services.

In the 1998 Comprehensive Spending Review (CSR98) the UK government set out to "root out waste and inefficiency" in public services by setting efficiency targets for key public services (HM Treasury, 1998). As part of CSR98 the government established "Best Value "to make local government services more efficient and effective" (HM Treasury, 1998). English councils had a "duty to deliver services to clear standards - covering both cost and quality - by the most economic, efficient and effective means available" (Audit Commission, 1999) and the government set English councils annual 2 per cent best value efficiency targets.

In 2000 in response to the 'Modernising Government' agenda, the Treasury formed the Public Services Productivity Panel. The aim of this panel was to "advise on ways of improving the productivity and efficiency of the public services" (Public Services Productivity Panel, 2000). The panel members were business and public sector leaders chosen to provide "a new perspective on some of the difficult issues that public services face in their drive to improve performance" (Public Services Productivity Panel, 2000). The panel's definition of productivity included 'economy, efficiency and effectiveness'.

In August 2003 The Prime Minister of the UK and the Chancellor of the Exchequer, invited Sir Peter Gershon to undertake an independent review of efficiency in the UK public sector. The remit of the review was to develop proposals to deliver efficiencies 
in the public sector and feed into the 2004 Spending Review by making recommendations to Ministers about departmental efficiency targets for the financial period 2005/06 to 2007/08 (Gershon, 2004). The review that was released in July 2004 and gave a headline figure of $£ 20$ billion of annual efficiencies that UK public services could achieve (Gershon, 2004).

In May 2010 a coalition government was elected in the UK. The new government emphasised the need for people to become more involved in the delivery of public services through volunteering and social enterprises (the 'Big Society' initiative) and by making local government more accountable through transparency of data and the information councils provide. In August 2010 the Department for Communities and Local Government (CLG) announced the abolition of the Audit Commission and the greater involvement of local people in the audit of local public services through 'armchair' auditing.

This paper is based on a secondary analysis of administrative data about English local councils called the Annual Efficiency Statements (AES) which for each financial year from 2005/06 to 2007/08 every council had to produce. The secondary analysis aims to understand the back office efficiency savings made by English councils during the 2004 Spending Review (SR04) period. This paper illustrates the degree of efficiency savings in English councils examining whether they are influenced by internal and external contextual factorsi. It will also reflect on, in light of recent UK Government changes, the influence of audit and inspection on the delivery of efficient services.

\section{The UK context of Service Performance in Local Government}

The last 15 years have seen a strong political and policy emphasis on improving public services in the UK (Benington, 2007) often under the banner of 'New Public Management (NPM). It is widely recognised that there are many different definitions of NPM but that there is also a fair overlap between most of them. A single phase may be difficult to give but Pollitt $(2003$, p27) cites an attempted to do so by stating NPM is "disaggregation + competition + incentivization". The New Public Management (NPM) movement has focused on improving business processes, empowerment of citizens and users and, the use of performance indicators or measures (Pollitt 2002). 
HM Government (1990, p 3) define a performance measure/ indicator as "a statement, often quantitative, about resources deployed and/or services provided in areas relevant to a particular objectives." The report continues to suggest that no single indicator is a perfect instrument so there should be a range of performance indicators in order to manage the service (HM Government, 1990). Often performance measurement is focused on efficiency, productivity and utilisation, whereas performance management builds on performance measurement and is concerned with effectiveness, improvement and a broader, more holistic view of the organisation (Radnor, 2009).

In the continuing drive for greater efficiency, the UK Government commissioned Sir Peter Gershon to conduct an independent review of how efficiency savings could be made in the public sector (Gershon, 2004). The review identified stretching efficiency targets for the public sector that could be implemented during the 2004 Spending Review (2004) period covering the financial years 2005/06 to 2007/08 in order to achieve efficiency savings as well as improve services (Gershon, 2004). Gershon identified efficiency in the public sector as "making the best use of resources available for the provision of public services" (Gershon, 2004: 6-7).

Gershon identified back office functions (i.e. finance, human resources, information technology support, procurement services, legal services, facilities management, and, marketing and communications) as a key area for efficiency savings highlighting methods including shared services, outsourcing, and internal rationalisation of services (Gershon, 2004).

As part of the remit of his independent review, Gershon made recommendations to UK Ministers about the level of efficiency savings that could be made in local government in the UK as part of the 2004 Spending Review (SR04). Gershon recommended that by 2007/08 local government could make efficiency savings of $2.5 \%$ per year to achieve $£ 6.45$ billion of efficiencies by 2007/08 (Gershon, 2004: 55). Councils also had to ensure that half of the annual $2.5 \%$ efficiency target was achieved through 'cashable' efficiency savings and the other half through 'noncashable' efficiency savings (Table 1 ).

Table 1 Definition of cashable and non-cashable savings 


\begin{tabular}{|l|l|l|}
\hline Efficiency action & Cashable or non-cashable \\
\hline Reduce inputs for the same outputs & Cashable & $\begin{array}{l}\text { Money is released } \\
\text { that can be reused } \\
\text { elsewhere }\end{array}$ \\
\hline Reduce prices for the same outputs & Cashable & $\begin{array}{l}\text { Money is not } \\
\text { released }\end{array}$ \\
\hline $\begin{array}{l}\text { Greater outputs or improved quality for the } \\
\text { same inputs }\end{array}$ & Non-cashable \\
\cline { 1 - 2 } $\begin{array}{l}\text { Greater outputs or improved quality in for a proportionately smaller increase } \\
\text { in resources }\end{array}$ & Non-cashable & \\
\hline
\end{tabular}

Source: Adapted from Communities and Local Government, published in Back to front: Back office efficiency gains in local government (Audit Commission, 2008)

During SR04 English local authorities had to report the efficiency savings they made on an annual basis to CLG using Annual Efficiency Statements (AES) (Office of the Deputy Prime Minister, 2005). At the beginning of each financial year councils reported the efficiency savings they expected to make in the 'forward look' AES. At the end of each financial year councils reported the efficiency savings they had achieved in the 'backward look' AES. Each council's AES was published by CLG and are publicly available and offer a rich source of secondary data that provides the opportunity to gain an understating of the efficiency savings that English councils made during SRO4ii.

Central government in Englandiii has taken several steps over the last decade to modernise local government through setting agendas such as efficiency, direct influence (legislation and policy) and, indirect influence (guidance and actions of auditors and inspectors).

'Best Value' set out the statutory principles for a modernised local government along with the inspection regime that would ensure change happened. Best Value came into effect on $1^{\text {st }}$ April 2000 (Bovaird and Halachmi, 2001). The Office of the Deputy Prime Minister (DETR, 1999) described Best Value as "one of the key means of delivering the Government's modernising agenda in local government. Best Value is defined as a duty to deliver services to clear standards (covering both cost and quality) by the most economic, efficient and effective means available." Under Best Value, local authorities were required to assess and challenge their own performance and put measures in place continually to improve services (Best Value Performance 
Indicators (BVPI)). Best Value was replaced by the inspection regime Comprehensive Performance Assessment (CPA) in April 2002, then the harder CPA before the Comprehensive Area Assessment (CAA) in April 2009. All which, after a decade of use together with audit and inspection, are in the process of being removed.

This paper's focus on efficiency savings aims to draw on the AES data to illustrate how secondary data can be used to understand the efficiency savings made by English councils during SR04 and, to explore efficiency within the context of the role of audit and inspection. In particular, therefore, this paper aims to answer the following research questions:

- Can secondary data sources be used to identify how efficiency savings and service improvements were made by English councils?

- Is there a relationship between efficiency savings made by English councils and internal and external contextual factors?

- How is the relationship between English councils performance in the delivery of efficient public services influenced by the role of audit and inspection?

\section{Methodology}

The units of analysis for this paper are the 388 single tier and county councils and district councils that existed in England before the reorganisation of some English councils came into effect on 1 April 2009 (Communities and Local Government, 2009). Of this total 150 English councils were single tier and county councils and 238 were district councils.

In England areas of high population density that are mainly urban, public services are delivered by single tier councils that provide, or commission, a range of services to the public including education, social care, welfare services and planning. In areas of low population density public services are delivered by two types of councils: district councils and county councils. County councils deliver public services such as education and social care to more than one local area and have budgets that are similar in size to single tier councils. District councils deliver public services such as environmental and welfare services to one local area and have budgets that are much smaller than county councils. 
For the purposes of analysis the single tier and county councils were grouped into one unit of analysis as both types of local authorities provide similar services to the public and have similar sized budgets. The district councils were grouped into a separate unit of analysis as the councils provide the same range of services to the public and have smaller budgets when compared to single tier and county councils. A third unit of analysis was created from all the 388 English councils, to provide a comparator for single tier and county councils and district councils.

This paper considers the back office efficiency savings made by English councils during SR04 because this was one of the key areas which Gershon identified that English councils could make significant efficiency savings. The baseline year for analysis was 2005/06 because this was the first year of the SR04 period and the first year when Gershon efficiency savings of 2.5 per cent came into affect.

For the purposes of analysis back office functions were based upon the following service areas from the AES:

- procurement;

- corporate services (e.g. finance, administration, marketing); and

- transactional services (e.g. revenues and benefits processing).

The AES data for the three years was analysed to determine the:

- total efficiency gains during SR04;

- if councils exceeded their predictions of total levels of efficiency savings during SR04;

- total back office efficiency gains;

- how back office and front line service efficiency gains contributed to the 7.5 per cent efficiency target; and

- the contribution of cashable and non-cashable efficiency savings to total back office efficiency gains.

Data from the AES was also compared against a number of external contextual factors to see if back office efficiency gains were influenced by external factors. The indicators that were chosen (see Table 2) were selected to give an indication of the socioeconomic makeup of each English council local area and reflect a standard set of indicators (including population and deprivation) used by Andrews and Boyne (2008) in their analysis of public sector service failure. 
Table 2 External contextual factors

\begin{tabular}{|l|l|}
\hline External contextual factor & Why chosen \\
\hline $\begin{array}{l}\text { Total population in 2005 population } \\
\text { (Source: Mid-year } \\
\text { estimates, Office for National Statistics) }\end{array}$ & $\begin{array}{l}\text { Provides a measure of the size of the } \\
\text { council in terms of residential population }\end{array}$ \\
\hline $\begin{array}{l}\text { Average house price in 2006 (£) } \\
\text { (Source: Office for National Statistics) }\end{array}$ & $\begin{array}{l}\text { Provides a measure of the cost of housing } \\
\text { and economic prosperity in a local area }\end{array}$ \\
\hline $\begin{array}{l}\text { Index of Multiple Deprivation (IMD) } \\
\text { 2004: Average score } \\
\text { (Source: Communities and Local } \\
\text { Government) }\end{array}$ & $\begin{array}{l}\text { Provides a measure of the level of } \\
\text { other council areas }\end{array}$ \\
\hline $\begin{array}{l}\text { Index of Multiple Deprivation (IMD) } \\
\text { 2004: Extent of deprivation } \\
\text { (Source: Communities and Local } \\
\text { Government) }\end{array}$ & $\begin{array}{l}\text { Provides a measure of the extent of } \\
\text { deprivation in a local area compared to } \\
\text { other council areas }\end{array}$ \\
\hline $\begin{array}{l}\text { Percentage of working age (16 to 65) } \\
\text { population in employment in 2006 } \\
\text { (Source: Office for National Statistics) }\end{array}$ & $\begin{array}{l}\text { Provides a measure of the economic } \\
\text { prosperity and employment opportunities in } \\
\text { a local area }\end{array}$ \\
\hline $\begin{array}{l}\text { Political control of English councils } \\
\text { (Source: Audit Commission) }\end{array}$ & $\begin{array}{l}\text { Provides a measure of political control of } \\
\text { councils in a local area }\end{array}$ \\
\hline
\end{tabular}

Scatter plots were used to test the relationships between back office efficiency savings and external contextual factors. Linear trend lines were then applied to these scatter plots to see if the $\mathrm{R}^{2}$ was significant. Multivariate model analysis was not undertaken because the bivariate tests highlighted that there was no statistically significant relationships between the variables.

Back office efficiency gains were also compared against nine Best Value Performance Indicators (BVPIs) that related to back office functions to understand if there was a relationship between internal contextual factors and back office efficiency savings. The performance indicators closely reflect back office functions such as planning applications and invoices paid that are common to all councils in England. The performance indicators that were used were:

- BV109a Planning applications: Major applications;

- BV109b Planning applications: Minor applications; 
- BV109c Planning applications: Other applications;

- BV12 Working days lost due to sickness absence;

- BV78a Speed of processing new claim to housing benefit/council tax benefit;

- BV78b Speed of processing change of circumstances to housing benefit/council tax benefit;

- BV79a Accuracy of housing benefit/council tax benefit claims;

- BV8 Percentage of invoices paid on time; and

- BV9 Percentage of council tax collected.

The BVPIs were standardised to show the percentage change in the performance indicators from 2002/03 to 2006/07. To test the relationships between back office efficiency savings and internal contextual factors, scatter plots were used to see if there was a relationship between the variables. Linear trend lines were then applied to these scatter plots to see if the $\mathrm{R}^{2}$ was significant. Multivariate model analysis was not undertaken because the bivariate tests highlighted that there was no statistically significant relationships between the variables.

\section{How do they do it?: Efficiency Results Achieved}

The analysis of the AES demonstrates that English councils beat the SR04 7.5 per cent efficiency target, making $£ 4.34$ billion of total efficiency gains during SR04 (Table 3).

Table 3 English councils achievement of the efficiency target

\begin{tabular}{|c|c|c|c|}
\hline Year & $\begin{array}{l}\text { Cumulative } \\
\text { efficiency target } \\
\text { (£bn) }\end{array}$ & $\begin{array}{l}\text { Efficiencies reported } \\
\text { (£bn) }\end{array}$ & $\begin{array}{l}\text { Excess over target } \\
\text { (Ebn) }\end{array}$ \\
\hline $2004 / 05$ & Nil & 0.76 & 0.76 \\
\hline $2005 / 06$ & 1.00 & 1.93 & 0.93 \\
\hline $2006 / 07$ & 2.01 & 3.06 & 1.05 \\
\hline $2007 / 08$ & 3.01 & 4.34 & 1.33 \\
\hline
\end{tabular}

Source: Audit Commission and Communities and Local Government, 2008 
Of this total back office efficiency savings accounted for $£ 1.2$ billion or 28 per cent of the total. Analysis of the AES data also demonstrates that English councils beat their predictions of efficiency gains throughout the SR04 period (Figure 1).

Figure 1 Actual and predicted efficiency gains during SR04

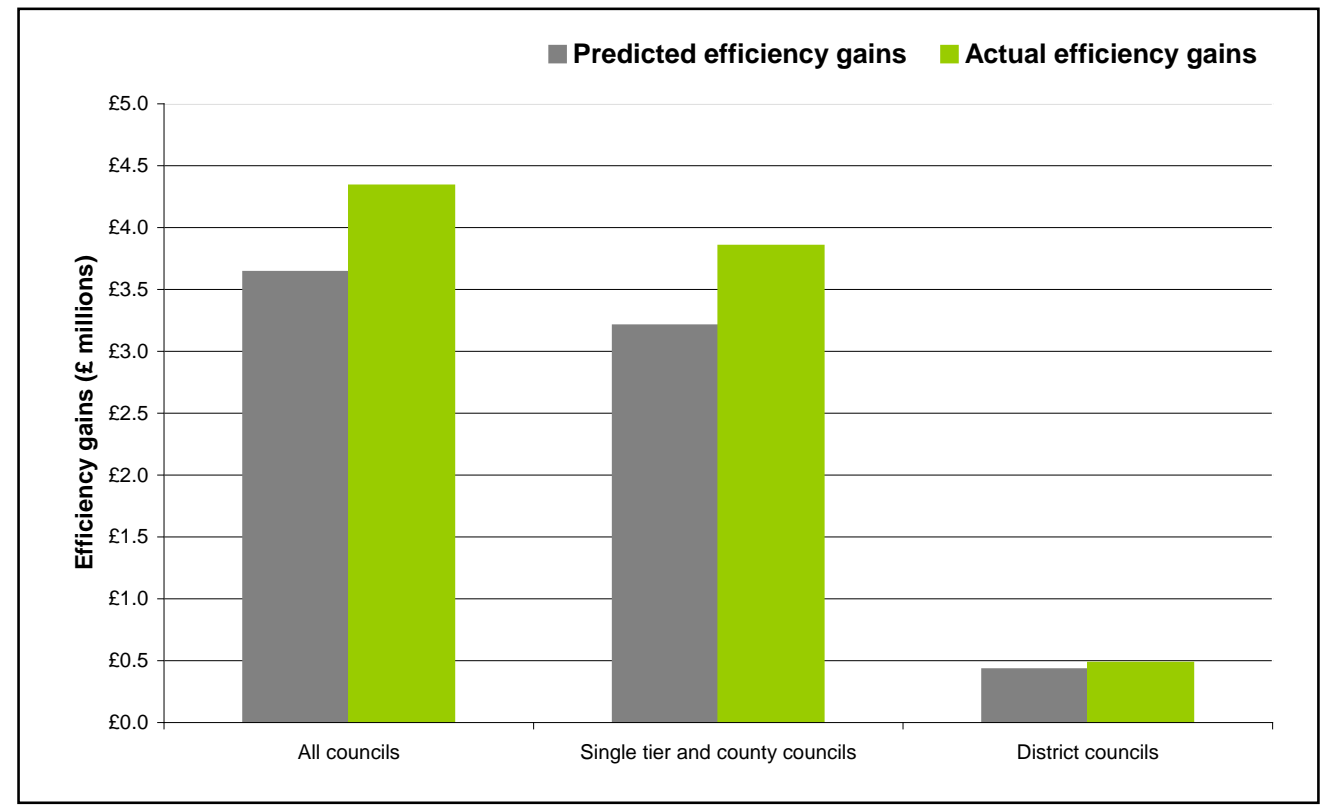

Source: Audit Commission, 2008

The contribution of the cashable and non-cashable efficiency gains

Figure 2 illustrates English councils made more cashable efficiency savings than non-cashable efficiency savings throughout SR04. More than four-fifths (84 per cent) of back office efficiency gains made by English councils during SRO4 were cashable efficiency savings. 
Figure 2 Cashable efficiency savings versus non-cashable efficiency gains during SR04

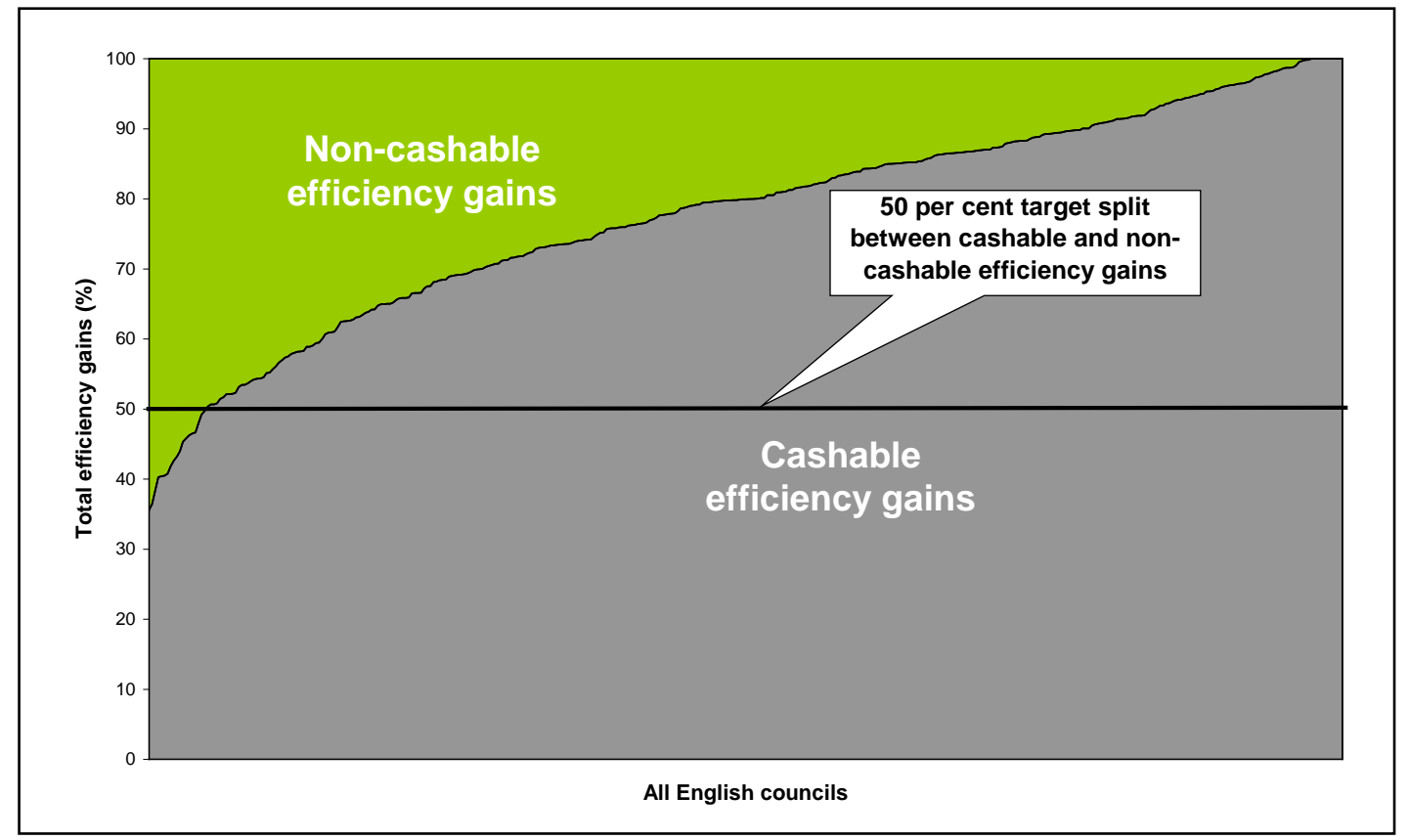

Source: Audit Commission, 2008

\section{Back office efficiency savings}

Analysis of the AES shows that the contribution of back office efficiency gains to total efficiency savings during SR04 varied amongst English councils (Figure 3). The contribution of back office efficiency gains in individual councils varied from 6 per cent to 91 per cent.

Figure 3 Back office efficiency gains contribution to total efficiency savings

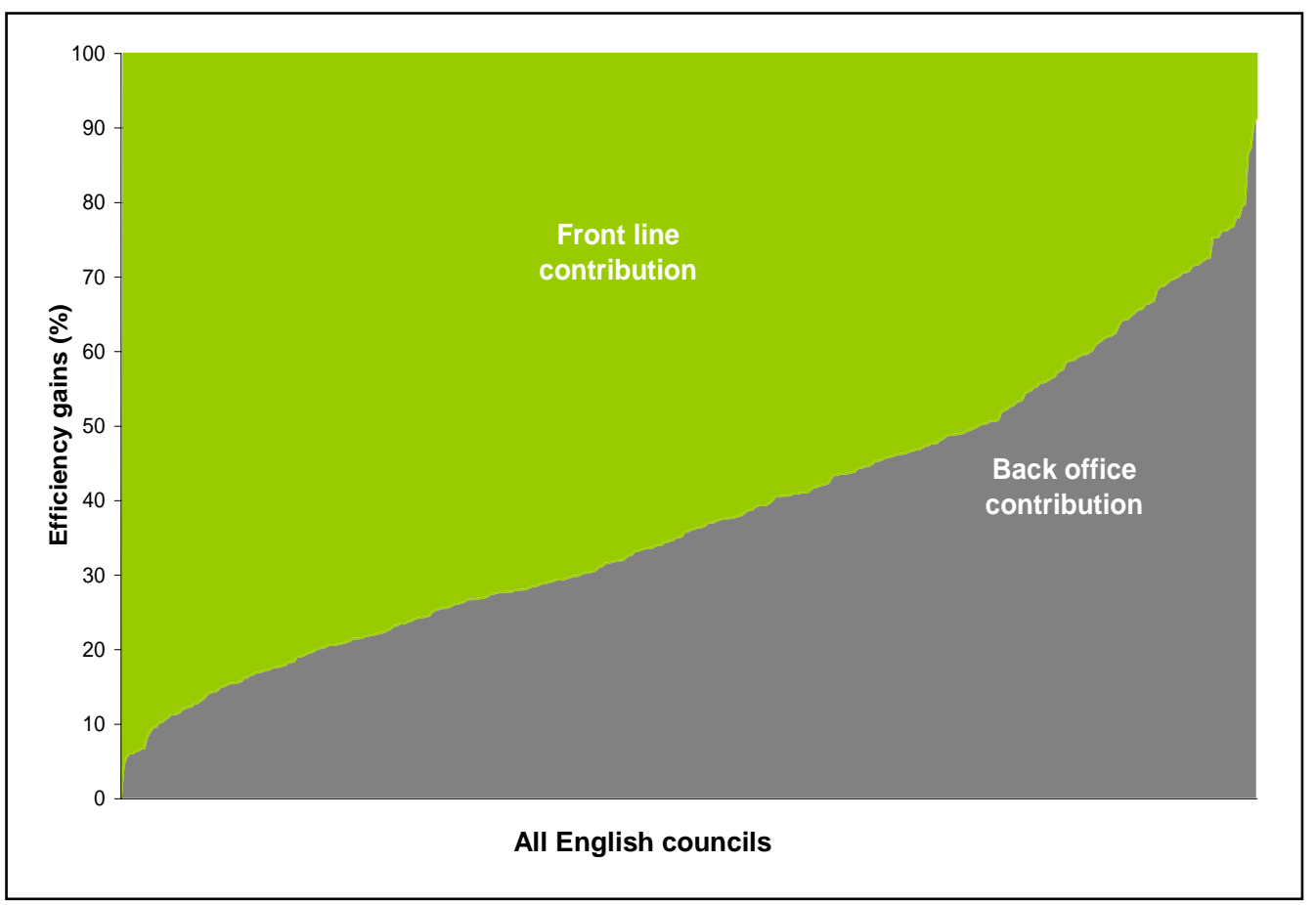


Source: Audit Commission, 2008

Tables 4 and 5 show the results of the examination of the relationship between back office efficiency savings and the contextual factors.

Table 4 Results of examination of the relationship between back office efficiency savings and internal contextual factors

\begin{tabular}{|c|c|c|c|c|c|c|c|c|c|c|c|c|}
\hline \multirow{3}{*}{$\begin{array}{l}\text { Internal contextual } \\
\text { factors: } \\
\text { BVPIs from } 2002 / 03 \\
\text { to } 2006 / 07\end{array}$} & \multicolumn{3}{|c|}{$\begin{array}{l}\text { Total back office gains } \\
\text { in } 2005 / 06 \text { as percentage } \\
\text { of total efficiency gains } \\
\text { in } 200506\end{array}$} & \multicolumn{3}{|c|}{$\begin{array}{l}\text { Total back office } \\
\text { efficiency gains in } \\
2006 / 07 \text { as a } \\
\text { percentage of total } \\
\text { efficiency gains in } \\
2006 / 07\end{array}$} & \multicolumn{3}{|c|}{$\begin{array}{l}\text { Total back office } \\
\text { cashable gains in } \\
2005 / 06 \text { as } \quad \text { a } \\
\text { percentage of total } \\
\text { cashable efficiency } \\
\text { gains in 2005/06 }\end{array}$} & \multicolumn{3}{|c|}{$\begin{array}{l}\text { Total back office cashable } \\
\text { gains in } 2006 / 07 \text { as a } \\
\text { percentage of total } \\
\text { cashable efficiency gains } \\
\text { in 2006/07 }\end{array}$} \\
\hline & $\begin{array}{l}\text { Single } \\
\text { tier and } \\
\text { county } \\
\text { councils }\end{array}$ & $\begin{array}{l}\text { Distr } \\
\text { ict } \\
\text { coun } \\
\text { cils }\end{array}$ & $\begin{array}{l}\text { All } \\
\text { counci } \\
\text { Is }\end{array}$ & $\begin{array}{l}\text { Single } \\
\text { tier } \\
\text { and } \\
\text { county } \\
\text { counci } \\
\text { Is }\end{array}$ & $\begin{array}{l}\text { Distr } \\
\text { ict } \\
\text { coun } \\
\text { cils }\end{array}$ & $\begin{array}{l}\text { All } \\
\text { coun } \\
\text { cils }\end{array}$ & $\begin{array}{l}\text { Single } \\
\text { tier } \\
\text { and } \\
\text { county } \\
\text { counci } \\
\text { Is }\end{array}$ & $\begin{array}{l}\text { Distr } \\
\text { ict } \\
\text { coun } \\
\text { cils }\end{array}$ & $\begin{array}{l}\text { All } \\
\text { counci } \\
\text { Is }\end{array}$ & $\begin{array}{l}\text { Sing } \\
\text {-le } \\
\text { tier } \\
\text { and } \\
\text { coun } \\
\text { ty } \\
\text { coun } \\
\text { cils }\end{array}$ & $\begin{array}{l}\text { District } \\
\text { counci } \\
\text { Is }\end{array}$ & $\begin{array}{l}\text { All } \\
\text { councils }\end{array}$ \\
\hline & $\mathrm{R}^{2}$ & $\mathrm{R}^{2}$ & $\mathrm{R}^{2}$ & $\mathrm{R}^{2}$ & $\mathrm{R}^{2}$ & $\mathrm{R}^{2}$ & $\mathrm{R}^{2}$ & $\mathrm{R}^{2}$ & $\mathrm{R}^{2}$ & $\mathrm{R}^{2}$ & $\mathrm{R}^{2}$ & $\mathrm{R}^{2}$ \\
\hline $\begin{array}{lr}\text { BV109a } & \text { Planning } \\
\text { applications: } & \text { Major } \\
\text { applications } & \end{array}$ & $<0.001$ & $\begin{array}{l}<0.0 \\
01\end{array}$ & $\begin{array}{l}<0.00 \\
1\end{array}$ & $\begin{array}{l}<0.00 \\
1\end{array}$ & $\begin{array}{l}0.00 \\
2\end{array}$ & $\begin{array}{l}0.00 \\
2\end{array}$ & $\begin{array}{l}<0.00 \\
1\end{array}$ & $\begin{array}{l}0.00 \\
1\end{array}$ & $\begin{array}{l}<0.00 \\
1\end{array}$ & $\begin{array}{l}<0.0 \\
01\end{array}$ & $\begin{array}{l}<0.00 \\
2\end{array}$ & 0.001 \\
\hline $\begin{array}{lr}\text { BV109b } & \text { Planning } \\
\text { applications: } & \text { Minor } \\
\text { applications } & \end{array}$ & 0.022 & $\begin{array}{l}0.00 \\
4\end{array}$ & 0.004 & 0.011 & $\begin{array}{l}0.00 \\
8\end{array}$ & $\begin{array}{l}0.00 \\
6\end{array}$ & 0.017 & $\begin{array}{l}0.00 \\
6\end{array}$ & 0.005 & $\begin{array}{l}0.01 \\
1\end{array}$ & 0.004 & 0.003 \\
\hline $\begin{array}{lr}\text { BV109c } & \text { Planning } \\
\text { applications: } & \text { Other } \\
\text { applications } & \end{array}$ & 0.012 & $\begin{array}{l}0.01 \\
1\end{array}$ & 0.004 & 0.004 & $\begin{array}{l}0.01 \\
6\end{array}$ & $\begin{array}{l}0.00 \\
5\end{array}$ & 0.003 & 0.01 & 0.003 & $\begin{array}{l}<0.0 \\
01\end{array}$ & 0.007 & 0.002 \\
\hline $\begin{array}{l}\text { BV12 Working days } \\
\text { lost due to sickness } \\
\text { absence }\end{array}$ & 0.003 & $\begin{array}{l}<0.0 \\
01\end{array}$ & $\begin{array}{l}<0.00 \\
1\end{array}$ & 0.004 & $\begin{array}{l}0.00 \\
3\end{array}$ & $\begin{array}{l}0.00 \\
3\end{array}$ & $\begin{array}{l}<0.00 \\
1\end{array}$ & $\begin{array}{l}0.00 \\
4\end{array}$ & 0.002 & $\begin{array}{l}<0.0 \\
01\end{array}$ & $\begin{array}{l}<0.00 \\
1\end{array}$ & $<0.001$ \\
\hline $\begin{array}{l}\text { BV78a Speed of } \\
\text { processing new claim } \\
\text { to housing } \\
\text { benefit/council tax } \\
\text { benefit }\end{array}$ & 0.028 & $\begin{array}{l}0.00 \\
1\end{array}$ & 0.002 & 0.024 & $\begin{array}{l}0.00 \\
3\end{array}$ & $\begin{array}{l}0.00 \\
4\end{array}$ & 0.022 & $\begin{array}{l}0.00 \\
2\end{array}$ & 0.003 & $\begin{array}{l}0.01 \\
3\end{array}$ & 0.001 & 0.003 \\
\hline $\begin{array}{l}\text { BV78b Speed of } \\
\text { processing change of } \\
\text { circumstances to } \\
\text { housing benefit/ } \\
\text { council tax benefit }\end{array}$ & $<0.001$ & $\begin{array}{l}0.00 \\
9\end{array}$ & 0.009 & 0.002 & $\begin{array}{l}0.01 \\
7\end{array}$ & $\begin{array}{l}0.01 \\
7\end{array}$ & 0.002 & $\begin{array}{l}0.00 \\
4\end{array}$ & 0.006 & $\begin{array}{l}0.00 \\
6\end{array}$ & 0.006 & 0.009 \\
\hline $\begin{array}{l}\text { BV79a Accuracy of } \\
\text { housing benefit/council } \\
\text { tax benefit claims }\end{array}$ & 0.008 & $\begin{array}{l}<0.0 \\
01\end{array}$ & 0.005 & 0.005 & $\begin{array}{l}0.00 \\
3\end{array}$ & $\begin{array}{l}0.01 \\
1\end{array}$ & 0.015 & $\begin{array}{l}<0.0 \\
01\end{array}$ & 0.007 & $\begin{array}{l}0.00 \\
7\end{array}$ & 0.002 & 0.011 \\
\hline
\end{tabular}




\begin{tabular}{|c|c|c|c|c|c|c|c|c|c|c|c|c|}
\hline \multirow{3}{*}{$\begin{array}{l}\text { Internal contextual } \\
\text { factors: } \quad \text { Indexed } \\
\text { BVPIs from } 2002 / 03 \\
\text { to 2006/07 }\end{array}$} & \multicolumn{3}{|c|}{$\begin{array}{l}\text { Total back office gains } \\
\text { in } 2005 / 06 \text { as percentage } \\
\text { of total efficiency gains } \\
\text { in } 200506\end{array}$} & \multicolumn{3}{|c|}{$\begin{array}{l}\text { Total back office } \\
\text { efficiency gains in } \\
2006 / 07 \text { as a } \\
\text { percentage of total } \\
\text { efficiency gains in } \\
2006 / 07\end{array}$} & \multicolumn{3}{|c|}{$\begin{array}{l}\text { Total back } r \text { office } \\
\text { cashable gains in } \\
2005 / 06 \text { as a } \\
\text { percentage of total } \\
\text { cashable efficiency } \\
\text { gains in 2005/06 }\end{array}$} & \multicolumn{3}{|c|}{$\begin{array}{l}\text { Total back office cashable } \\
\text { gains in } 2006 / 07 \text { as } \\
\text { percentage of tota } \\
\text { cashable efficiency gains } \\
\text { in } 2006 / 07\end{array}$} \\
\hline & $\begin{array}{l}\text { Single } \\
\text { tier and } \\
\text { county } \\
\text { councils }\end{array}$ & $\begin{array}{l}\text { Distr } \\
\text { ict } \\
\text { coun } \\
\text { cils }\end{array}$ & $\begin{array}{l}\text { All } \\
\text { counci } \\
\text { Is }\end{array}$ & $\begin{array}{l}\text { Single } \\
\text { tier } \\
\text { and } \\
\text { county } \\
\text { counci } \\
\text { Is }\end{array}$ & $\begin{array}{l}\text { Distr } \\
\text { ict } \\
\text { coun } \\
\text { cils }\end{array}$ & $\begin{array}{l}\text { All } \\
\text { coun } \\
\text { cils }\end{array}$ & $\begin{array}{l}\text { Single } \\
\text { tier } \\
\text { and } \\
\text { county } \\
\text { counci } \\
\text { Is }\end{array}$ & $\begin{array}{l}\text { Distr } \\
\text { ict } \\
\text { coun } \\
\text { cils }\end{array}$ & $\begin{array}{l}\text { All } \\
\text { counci } \\
\text { Is }\end{array}$ & $\begin{array}{l}\text { Sing } \\
\text {-le } \\
\text { tier } \\
\text { and } \\
\text { coun } \\
\text { ty } \\
\text { coun } \\
\text { cils }\end{array}$ & $\begin{array}{l}\text { District } \\
\text { counci } \\
\text { Is }\end{array}$ & $\begin{array}{l}\text { All } \\
\text { councils }\end{array}$ \\
\hline & $\mathrm{R}^{2}$ & $\mathrm{R}^{2}$ & $\mathrm{R}^{2}$ & $\mathrm{R}^{2}$ & $\mathrm{R}^{2}$ & $\mathrm{R}^{2}$ & $\mathrm{R}^{2}$ & $\mathrm{R}^{2}$ & $\mathrm{R}^{2}$ & $\mathrm{R}^{2}$ & $\mathrm{R}^{2}$ & $\mathrm{R}^{2}$ \\
\hline $\begin{array}{l}\text { BV8 Percentage of } \\
\text { invoices paid on time }\end{array}$ & 0.018 & $\begin{array}{l}<0.0 \\
01\end{array}$ & 0.002 & 0.008 & $\begin{array}{l}<0.0 \\
01\end{array}$ & $\begin{array}{l}0.00 \\
8\end{array}$ & 0.019 & $\begin{array}{l}<0.0 \\
01\end{array}$ & 0.007 & $\begin{array}{l}0.00 \\
4\end{array}$ & 0.005 & 0.015 \\
\hline $\begin{array}{l}\text { BV9 Percentage of } \\
\text { council tax collected }\end{array}$ & 0.003 & $\begin{array}{l}0.01 \\
4\end{array}$ & $\begin{array}{l}<0.00 \\
1\end{array}$ & 0.006 & $\begin{array}{l}0.00 \\
2\end{array}$ & $\begin{array}{l}0.00 \\
3\end{array}$ & 0.01 & $\begin{array}{l}0.00 \\
8\end{array}$ & 0.002 & $\begin{array}{l}0.02 \\
3\end{array}$ & 0.007 & 0.003 \\
\hline
\end{tabular}

Source: Audit Commission, 2008

Table 5 Results of examination of the relationship between back office efficiency savings and external contextual factors

\begin{tabular}{|c|c|c|c|c|c|c|c|c|c|c|c|c|}
\hline \multirow{3}{*}{$\begin{array}{l}\text { External } \\
\text { contextual } \\
\text { factors }\end{array}$} & \multicolumn{3}{|c|}{$\begin{array}{l}\text { Total back office } \\
\text { gains in } 2005 / 06 \text { as } \\
\text { percentage of total } \\
\text { efficiency gains in } \\
200506\end{array}$} & \multicolumn{3}{|c|}{$\begin{array}{l}\text { Total back office } \\
\text { efficiency gains in } \\
2006 / 07 \text { as a } \\
\text { percentage of total } \\
\text { efficiency gains in } \\
2006 / 07\end{array}$} & \multicolumn{3}{|c|}{ 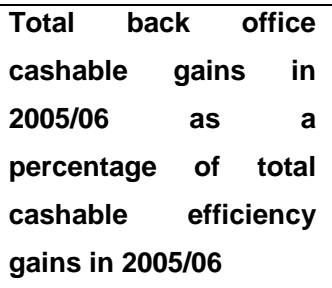 } & \multicolumn{3}{|c|}{$\begin{array}{l}\text { Total back office cashable gains in } \\
2006 / 07 \text { as a percentage of total } \\
\text { cashable efficiency gains in } 2006 / 07\end{array}$} \\
\hline & $\begin{array}{l}\text { Sing } \\
\text { le } \\
\text { tier } \\
\text { and } \\
\text { coun } \\
\text { ty } \\
\text { coun } \\
\text { cils }\end{array}$ & $\begin{array}{l}\text { Distr } \\
\text { ict } \\
\text { coun } \\
\text { cils }\end{array}$ & $\begin{array}{l}\text { All } \\
\text { counci } \\
\text { Is }\end{array}$ & $\begin{array}{l}\text { Single } \\
\text { tier } \\
\text { and } \\
\text { county } \\
\text { counci } \\
\text { Is }\end{array}$ & $\begin{array}{l}\text { District } \\
\text { counci } \\
\text { Is }\end{array}$ & $\begin{array}{l}\text { All } \\
\text { coun } \\
\text { cils }\end{array}$ & $\begin{array}{l}\text { Single } \\
\text { tier } \\
\text { and } \\
\text { county } \\
\text { counci } \\
\text { Is }\end{array}$ & $\begin{array}{l}\text { District } \\
\text { counci } \\
\text { Is }\end{array}$ & $\begin{array}{l}\text { All } \\
\text { coun } \\
\text { cils }\end{array}$ & $\begin{array}{l}\text { Single } \\
\text { tier and } \\
\text { county } \\
\text { councils }\end{array}$ & $\begin{array}{l}\text { District } \\
\text { councils }\end{array}$ & All councils \\
\hline & $\mathrm{R}^{2}$ & $\mathrm{R}^{2}$ & $\mathrm{R}^{2}$ & $\mathrm{R}^{2}$ & $\mathrm{R}^{2}$ & $\mathrm{R}^{2}$ & $\mathrm{R}^{2}$ & $\mathrm{R}^{2}$ & $\mathrm{R}^{2}$ & $\mathrm{R}^{2}$ & $\mathrm{R}^{2}$ & $\mathrm{R}^{2}$ \\
\hline $\begin{array}{l}\text { Total } \\
\text { population } \\
2005 \text { (mid- } \\
\text { year } \\
\text { population } \\
\text { estimate) }\end{array}$ & $\begin{array}{l}0.02 \\
2\end{array}$ & $\begin{array}{l}0.00 \\
2\end{array}$ & 0.093 & 0.028 & 0.001 & $\begin{array}{l}0.10 \\
2\end{array}$ & 0.009 & $\begin{array}{l}<0.00 \\
1\end{array}$ & $\begin{array}{l}0.08 \\
6\end{array}$ & 0.026 & $<0.001$ & 0.096 \\
\hline $\begin{array}{l}\text { Percentage } \\
\text { of working } \\
\text { age } \\
\text { population }\end{array}$ & $\begin{array}{l}0.00 \\
9\end{array}$ & $\begin{array}{l}<0.0 \\
01\end{array}$ & 0.019 & 0.026 & 0.001 & $\begin{array}{l}0.02 \\
6\end{array}$ & 0.006 & 0.004 & $\begin{array}{l}0.01 \\
4\end{array}$ & 0.027 & 0.002 & 0.012 \\
\hline
\end{tabular}




\begin{tabular}{|c|c|c|c|c|c|c|c|c|c|c|c|c|}
\hline \multirow{3}{*}{$\begin{array}{l}\text { External } \\
\text { contextual } \\
\text { factors }\end{array}$} & \multicolumn{3}{|c|}{$\begin{array}{l}\text { Total back office } \\
\text { gains in } 2005 / 06 \text { as } \\
\text { percentage of total } \\
\text { efficiency gains in } \\
200506\end{array}$} & \multicolumn{3}{|c|}{$\begin{array}{l}\text { Total back office } \\
\text { efficiency gains in } \\
2006 / 07 \text { as a } \\
\text { percentage of total } \\
\text { efficiency gains in } \\
2006 / 07\end{array}$} & \multicolumn{3}{|c|}{$\begin{array}{l}\text { Total back office } \\
\text { cashable gains in } \\
2005 / 06 \text { as a } \\
\text { percentage of total } \\
\text { cashable efficiency } \\
\text { gains in 2005/06 }\end{array}$} & \multicolumn{3}{|c|}{$\begin{array}{l}\text { Total back office cashable gains in } \\
2006 / 07 \text { as a percentage of tota } \\
\text { cashable efficiency gains in } 2006 / 07\end{array}$} \\
\hline & $\begin{array}{l}\text { Sing } \\
\text { le } \\
\text { tier } \\
\text { and } \\
\text { coun } \\
\text { ty } \\
\text { coun } \\
\text { cils }\end{array}$ & $\begin{array}{l}\text { Distr } \\
\text { ict } \\
\text { coun } \\
\text { cils }\end{array}$ & $\begin{array}{l}\text { All } \\
\text { counci } \\
\text { Is }\end{array}$ & $\begin{array}{l}\text { Single } \\
\text { tier } \\
\text { and } \\
\text { county } \\
\text { counci } \\
\text { Is }\end{array}$ & $\begin{array}{l}\text { District } \\
\text { counci } \\
\text { Is }\end{array}$ & $\begin{array}{l}\text { All } \\
\text { coun } \\
\text { cils }\end{array}$ & $\begin{array}{l}\text { Single } \\
\text { tier } \\
\text { and } \\
\text { county } \\
\text { counci } \\
\text { Is }\end{array}$ & $\begin{array}{l}\text { District } \\
\text { counci } \\
\text { Is }\end{array}$ & $\begin{array}{l}\text { All } \\
\text { coun } \\
\text { cils }\end{array}$ & $\begin{array}{l}\text { Single } \\
\text { tier and } \\
\text { county } \\
\text { councils }\end{array}$ & $\begin{array}{l}\text { District } \\
\text { councils }\end{array}$ & All councils \\
\hline & $\mathrm{R}^{2}$ & $\mathrm{R}^{2}$ & $\mathrm{R}^{2}$ & $\mathrm{R}^{2}$ & $\mathrm{R}^{2}$ & $\mathrm{R}^{2}$ & $\mathrm{R}^{2}$ & $\mathrm{R}^{2}$ & $\mathrm{R}^{2}$ & $\mathrm{R}^{2}$ & $\mathrm{R}^{2}$ & $\mathrm{R}^{2}$ \\
\hline \multicolumn{13}{|l|}{$\begin{array}{l}\text { (16 to } 65) \text { in } \\
\text { employment } \\
\text { in } 2006\end{array}$} \\
\hline $\begin{array}{l}\text { Average } \\
\text { house price } \\
(£) \text { in } 2006\end{array}$ & $\begin{array}{l}<0.0 \\
01\end{array}$ & $\begin{array}{l}0.00 \\
3\end{array}$ & $\begin{array}{l}<0.00 \\
1\end{array}$ & $\begin{array}{l}<0.00 \\
1\end{array}$ & 0.001 & $\begin{array}{l}<0.0 \\
01\end{array}$ & $\begin{array}{l}<0.00 \\
1\end{array}$ & 0.004 & $\begin{array}{l}<0.0 \\
01\end{array}$ & $<0.001$ & 0.002 & $<0.001$ \\
\hline $\begin{array}{l}\text { Index of } \\
\text { Deprivation } \\
\text { 2004: } \\
\text { Average } \\
\text { score }\end{array}$ & $\begin{array}{l}0.01 \\
1\end{array}$ & $\begin{array}{l}0.00 \\
2\end{array}$ & 0.02 & 0.018 & $\begin{array}{l}<0.00 \\
1\end{array}$ & $\begin{array}{l}0.03 \\
3\end{array}$ & 0.007 & 0.008 & $\begin{array}{l}0.01 \\
7\end{array}$ & 0.021 & $<0.001$ & 0.025 \\
\hline $\begin{array}{l}\text { Index of } \\
\text { Deprivation } \\
\text { 2004: } \\
\text { Deprivation } \\
\text { extent }\end{array}$ & 0.01 & $\begin{array}{l}<0.0 \\
01\end{array}$ & 0.027 & 0.019 & 0.004 & $\begin{array}{l}0.03 \\
9\end{array}$ & 0.007 & 0.004 & $\begin{array}{l}0.02 \\
4\end{array}$ & 0.017 & $<0.001$ & 0.032 \\
\hline
\end{tabular}

Source: Audit Commission, 2008

The analysis shows that for single tier and county councils, district councils and all councils, there was no $\mathrm{R}^{2}$ result that showed a statistically significant relationship between the back office efficiency savings and the internal (table 4) or external (table 5) contextual factors.

This suggests that the process of making back office efficiency savings in English councils is not influenced by internal or external contextual factors in terms of particular BVPIs or population or deprivation figures. It could mean that the efficiency savings are achieved in isolation. In other words, the findings indicate that in responding to the efficiency agenda the focus of managers and staff in the councils could be on achieving the particular output or result (in this case the savings) without 
considering the context of the authority or local needs. This, with other explanations will be considered further in the discussion.

\section{Discussion and Conclusion}

By drawing on the data set AES this paper has attempted to understand what back office efficiency savings were made by English councils. The results presented show that during SR04 English councils beat the SR04 7.5 per cent efficiency, making $£ 4.34$ billion of total efficiency gains and councils beat their predictions of efficiency savings. Of this total back office efficiency gains accounted for $£ 1.2$ billion or 28 per cent of the total. More than four-fifths (84 per cent) of the back office efficiency savings made by English councils during SR04 were cashable efficiency savings. The results presented also show that there is no relationship between back office efficiency savings and internal and external contextual factors.

The first research question asks if secondary data sources be used to identify how efficiency savings and service improvements were made by English councils? This paper has shown how councils have made efficiency savings during SR04. The analysis of the AES shows how secondary data can also be used to understand the relationships between different datasets. Similar to other research on performance in local government this paper has also shown that administrative data sources provide a rich source of evidence for research into the public sector. Andrews and Boyne (2008) illustrated how useful secondary data sources such as deprivation scores can be to understand failure in public sector organisations in England. Andrews and Boyne (2006) also used secondary data (corporate spend data) to show how larger English councils are more likely to get economies of scale in back office functions in comparison to smaller English councils.

The data analysis highlighted in this paper was used as part of the wider research for the Audit Commission National Study, Back to front: Efficiency of back office functions in local government. The national study report highlighted how English councils made efficiency savings during SR04 (Audit Commission, 2008). Data from the AES was used to select 23 councils for qualitative case studies and to highlight how these case studies had made efficiency savings. For example all 23 case study sites made procurement efficiency savings from 2005/06 to 2007/08; ranging from a district council that saved $£ 42,000$, to a metropolitan borough council that saved $£ 7$ million over the same period (Audit Commission, 2008: 41). 
Whilst the answer to the first question may not be surprising the answer to the second question raises more questions. It asks if there is a relationship between efficiency savings made by English councils and internal and external contextual factors? In other words when aiming to achieve efficiency savings does the local authority take into account their context? The analysis of back office efficiency saving and the relationship to internal contextual factors through a set of BVPIs that related to back office functions and council tax collection rates highlighted no relationship. The relationship of external factors, through population and deprivation figures, with efficiency savings again highlighted little relationship. This suggests that the process of making back office efficiency savings in English councils is not influenced or affected by internal or external contextual factors.

The findings in this paper indicate that the current focus on efficiency targets is independent to local context. This is supported by the finding of the level of cashable savings. Figure 2 clearly illustrates that the gain from cashable savings are higher than non-cashable. This maybe because cashable savings are much 'easier' to achieve, i.e. reducing stationary, reduction of headcount etc, or it might be because they are easier to count and audit, they are more flexible (they produce money), or they are linked to a contextual factor not considered (e.g. the level of council tax increase). Achieving non-cashable savings may mean a change in processes, relationships or systems. Therefore, it could be argued that once a greater focus is placed onto non-cashable savings the result should see a change in the measures and indicators used by councils maybe linked to the National Indicator Set (NIS) with more focus on time and quality directly related to delivery. Then a stronger relationship should be calculated between internal contextual factors and efficiency savings indicating a possible move from performance measurement and reporting to performance management. If a relationship was not detected in future this may highlight that 'gaming' (Radnor, 2008) has and is occurring either in the reporting of the NIS or the efficiency savings or both! This would indicate that the context and local needs are 'ignored' in order to achieve a result - in this case the efficiency savings target.

Similar findings regarding the relationship between a policy and context also occurred in the evaluation of another UK modernisation agenda - The Beacon Scheme. In this study relationships were sought and analysed on the relationship between the impact of contextual, institutional and management factors on 
organisational performance and, engagement in The Beacon Scheme. Across Rounds 1 to 7 of the Beacon Scheme through analysis of related BVPIs, population and deprivation data with results of a survey focused on the Beacon Scheme the only internal authority characteristic that was found to predict repeated and successful involvement with the Beacon Scheme was attendance at Beacon learning events (Withers, 2007).

Other limited empirical studies which have looked at the influence of context upon local authority outcomes also have had interesting results. For example, Boyne (1996) found mixed evidence on the effects of authority size on performance: fewer than half the empirical results showed that small authorities perform best, however the very largest authorities also performed well against the same indicators whilst, 'medium-sized' authorities performed least well. Boyne therefore concluded that the impact of authority size and subsequent scale varied across service and performance indicators and that there is 'no one optimum scale of service provision' (Boyne, 1996:824). Research by Boyne et al (2005) showed that local authority service performance was significantly constrained by local circumstances beyond council control, including diverse service needs. This research points to the fact that it is not only management processes and decisions but also conditions potentially beyond organisational control that influence organisational outcomes.

Reflecting on the findings above, and in this paper, there is an indication that when making decisions on modernisation agenda initiatives and policy within local authorities the focus is often on achieving the 'result' or 'target' (for this paper it was the efficiency savings) without consideration of the context. In their analysis of the Local Government Modernisation Agenda (LGMA) Downe and Martin (2006) found that most of the officials interviewed "did not recognise the notion of interrelated polices" (Downe and Martin, 2006: 481). However, in concluding they note that although the LGMA appears to be a succession of largely unrelated initiatives and programme of reform not supported through central government 'joining up' the local authorities managers themselves are attempting to 'own' the initiatives, develop and evolve strategy in order to impact service improvement (Downe and Martin, 2006).

The discussion above helps to consider the third question which asks how the relationship between councils drive for efficient services, which to date have been driven by government agendas and policies, is influenced by audit and inspection. This is interesting given that their role within England is currently being significantly 
reduced. The new coalition government has rejected many parts of the modernisation agenda but has strengthened the role of the 'localism' agenda. The localism agenda has emphasised the role of local people in making judgements about whether councils have delivered value for money in public services. This in theory means that the targets related to savings and key performance indicators will reduce along with the role of audit and inspection. This research has showed that the efficiency targets led to significant savings but the savings were not influenced by contextual factors and could have driven 'gaming' behaviours (Radnor, 2008). Therefore, it could be argued that the role of audit and inspection through performance indicators and targets has produced a focus on the wrong thing i.e. hitting the target but, it could also be argued that the presence of audit and inspection has had a role in 'setting direction'. What this analysis indicates and raises are interesting questions to 'how' the efficiency savings are being achieved, and to suggest that maybe to make further efficiency savings English councils need to better understand the context of their modernisation strategy and policies to drive not only achievement of the results but also improvement of service performance. In this sense the new agenda may allow, particularly the high performing councils, to response more clearly to their context and continue to drive not only efficient but effective services.

For the academic community the findings from this research raise questions about how, now with the reduced focus on the role of performance indicators and measures and audit and inspection, policy makers and managers within local government manage, drive, monitor and report performance improvement in their service delivery. For the current climate in the UK, particularly England, where after over a decade of measures and inspection this gives a opportunity to research and develop further knowledge on improvement and innovation where the boundaries for change is becoming more about administration and less about management.

\section{Disclaimer}

The Audit Commission has agreed that its research on back office efficiency savings carried out during 2008 can be used in this paper. The views expressed in the paper are solely those of the authors.

\section{Acknowledgements}

XXXXX would like to thank Peter Wilkinson, Michael Hughes, Sarah Furlong, and Agnieszka Scott for allowing her to use the Audit Commission research in writing this 
paper and for their support and encouragement enabling her to contribute to this paper.

\section{References}

Andrews, R and Boyne, G, (2008) 'Organizational environments and public-service failure: an empirical analysis', Environment and Planning C: Government and Policy, volume 26 , pp. $788-807$

Andrews, R and Boyne, G (2006), 'Size, Structure and Administrative Overheads: An Empirical Analysis of English Local Authorities', paper given at The Determinants of Performance in Public Organizations II Conference, University of Hong Kong, December

Audit Commission, (2008), Back to front: Efficiency of back office functions in local government, Audit Commission, London

Audit Commission, (1999), Best assured: The role of the Audit Commission in best value, Audit Commission, London

Benington J (2007) The reform of public services London: Stationery Office and National School of Government.

Boyne, George A, Gould-Williams Julian S, Law, Jennifer and Walker, Richard M (2005), 'Explaining the adoption of innovation: an empirical analysis of public management reform', Environment and Planning C: Government and Policy, volume 23, pp. 419-435

Boyne, G and Law, J, (2005) 'Setting Public Service Outcome Targets: Lessons from Local Public Service Agreements', Public Money \& Management, August, pp. 253260

Boyne, G (1996), 'Scale, Performance and Local Government Reorganization: An Analysis of the Non-Metropolitan Districts', Public Money \& Management, JulySeptember, pp. 55-60

Bovaird, T. and Halachmi, A. (2001) Performance Measurement and Best Value: an international perspective, International Journal of Business Performance Management, $\mathrm{Vol} 3$, Issue 2/3/4, pp 119-134

Communities and Local Government, (2009), Unitary Councils 2009 [Online], Available at: http://www.communities.gov.uk/localgovernment/restructuring/newunitarycouncils/ (Accessed 16 July 2009)

Downe, J and Martin S (2006), 'Joined up Policy and Practice? The Coherence and Impacts of the Local Government Modernisation Agenda', Local Government Studies, Vol 32, No 4, pp 465-288 
DETR (199), Local Government Act 1999 part One: Best Value, London

Gershon, P, (2004), Releasing resources to the front line, HM Treasury, London

Hartley, J., Butler, M. J. R. and Benington, J. (2002) Local Government modernisation: UK and comparative analysis from an organisational perspective, Public Management Review, Vol 4, Iss 3, pp387-404

HM Government (1990), Measuring up: performance Indicators in Further Education, HMSO, London.

HM Treasury, (1998), Pocket guide to Modern Services for Britain: Investing in reform, HM Treasury, London

Office of the Deputy Prime Minister, 2005), Efficiency Technical Note (ETN) for Local Government, Office of the Deputy Prime Minister, London

Pollitt, C. (2003). The Essential Public Manager. Philadelphia, Open University Press

Pollitt, C. (2002). 'Clarifying Convergence.' Public Management Review 4,1, 471-492.

Public Services Productivity Panel (2000). Public Services Productivity: Meeting the challenge. HM Treasury, London.

Radnor Z.J. (2009) "Understanding the Relationship between a National Award Scheme and Performance", International Review of Administrative Sciences, Vol 75, Issue 3, September, pp 437-457.

Radnor, Z. (2008), Muddled, massaging, manoeuvring or manipulated? A typology of organisational gaming, International Journal of Productivity and Performance Management, Vol 57, No 4, pp $316-328$

Withers, E., (2007), Predicators of Beaconicity, FIN03_07

\section{Notes}

\footnotetext{
i This paper is partly based upon research conducted for an Audit Commission National Study entitled Back to front: Efficiency of back office functions in local government (Audit Commission, 2008). The Audit Commission is an independent watchdog driving economy, efficiency and effectiveness in local public services to deliver better outcomes for everyone. Our work across local government, health, housing, community safety and fire and rescue services means that we have a unique perspective. We promote value for money for taxpayers, covering the $£ 180$ billion spent by 11,000 local public bodies. As a force for improvement, we work in partnership to assess local public services and make practical recommendations for promoting a better quality of life for local people. For further information about the Audit Commission, visit our website at www.audit-commission.gov.uk .

ii The AES are publicly available through Communities and Local Government. The AES can be found at: http://www.communities.gov.uk/localgovernment/efficiencybetter/deliveringefficiency/aes/. iii Devolution in the UK means that local government in Wales, Scotland, and Northern Ireland has taken different modernisation paths than that in England. The AES data only exists for councils in England.
} 